Note

\section{Thermally Induced Gelation of Sesame 13S Globulin Acylated with Maleic and Citraconic Anhydrides}

\author{
Kiyozo Hasegawa, Sachiyo Fujino, \\ Ikuko OKADO, Katsuko SuENOBU \\ and Masaaki Hirose*
}

\begin{abstract}
Department of Food Science and Nutrition, Nara Women's University, Nara 630, Japan
\end{abstract}

Received January 16, 1985

Although chemical modification has been widely used as a tool for improving the chemical and physical properties of food proteins, problems concerning the safety for eating remain to be solved. In previous reports, we have shown that thermally induced gelation of sesame $13 \mathrm{~S}$ globulin can be brought about under alkaline conditions, but not under acidic conditions. ${ }^{1 \sim 3)}$ However, under the alkaline conditions, artificial intramolecular crosslinkages such as lysinoalanine may be formed. ${ }^{4)}$ In this report, the effects of reversibly converting amino groups to carboxylate anions on the gelation of $13 \mathrm{~S}$ globulin were investigated. We found that the globulin modified with maleic or citraconic anhydrides can form gels by thermal treatment under acidic conditions. In addition, the carboxylate anions in a modified globulin were found to be reversed to original free amino groups during the thermal treatment for gelation.

The 13S globulin (extract II) was prepared from sesame seeds as described previously. ${ }^{1)}$ Acylation was carried out essentially as described by Butler and Hartley. ${ }^{5)}$ To the protein solution $(1.6 \mathrm{~g}$ per $80 \mathrm{ml}$ of $1 \mathrm{M} \mathrm{NaCl}), 40 \mathrm{mg}$ or $400 \mathrm{mg}$ of maleic anhydride, or $400 \mathrm{mg}$ of citraconic anhydride were slowly added. The solutions were maintained at $\mathrm{pH} 8.5 \sim 9.0$ and $\mathrm{pH} 8.0 \sim 8.5$ during modification by the maleic and citraconic anhydrides, respectively. After the solutions had been incubated for $30 \mathrm{~min}$ at $0^{\circ} \mathrm{C}$, they were dialyzed against distilled water, and then lyophilized. The two globulin samples modified with maleic anhydride are termed $\mathrm{Mal}_{1}{ }^{-}$, and $\mathrm{Mal}_{2}$-globulin, and the globulin sample modified with citraconic anhydride is termed Cit-globulin. The proteins were dissolved in distilled water in test tubes, and the solutions were adjusted to $8 \%$ concentration and $\mathrm{pH} 3.0$ at $0^{\circ} \mathrm{C}$ by adding dilute $\mathrm{HCl}$ solution. The samples were treated at $60^{\circ} \mathrm{C}$ or $70^{\circ} \mathrm{C}$ for $20 \mathrm{~min}$, and then rapidly cooled in a water bath containing ice. The extent of gelation was macroscopically estimated by inverting the test tubes to check whether the contents were fixed.

Table I shows that no gel was formed by incubating the native $13 \mathrm{~S}$ globulin solution at either $60^{\circ} \mathrm{C}$ or $70^{\circ} \mathrm{C}$. In contrast, hard gels were formed when the $\mathrm{Mal}_{1}{ }^{-}, \mathrm{Mal}_{2}-$ and Cit-globulin solutions were incubated at $70^{\circ} \mathrm{C}$. Thermally induced gels were also formed at $60^{\circ} \mathrm{C}$, although they were less hard. Therefore, modification with maleic and citraconic anhydrides appears to improve the gelation properties of sesame $13 \mathrm{~S}$ globulin.

The number of free amino groups in the native and modified globulins was estimated in $5 \mathrm{~mm} \mathrm{Na}$-borate buffer, $\mathrm{pH} 9.5$, containing $0.5 \mathrm{~mm}$ sodium dodecyl sulfate both before and after gelation treatment by the technique using trinitrobenzene sulfonate. ${ }^{6)}$ After the thermal treatment, the gels were dissolved in $0.19 \mathrm{M}$ sodium dodecyl sulfate. The samples were diluted with $10 \mathrm{~mm}$ Na-borate buffer, $\mathrm{pH} 9.5$, and the free amino groups determined. As shown in Table I, before the gelation treatment, $51 \%, 81 \%$

Table I. Gelation of Sesame 13S Globulin

\begin{tabular}{|c|c|c|c|}
\hline Protein & $\begin{array}{c}\text { Treatment } \\
\text { at } \mathrm{pH} 3\end{array}$ & Gelation $^{a}$ & $\begin{array}{l}\text { TNBS-reactive } \\
\text { amino group } \\
(\%)^{b}\end{array}$ \\
\hline \multirow[t]{3}{*}{ Native globulin } & N.T. ${ }^{c}$ & & 100 \\
\hline & $60^{\circ} \mathrm{C}$ & - & 106 \\
\hline & $70^{\circ} \mathrm{C}$ & - & 108 \\
\hline \multirow[t]{3}{*}{$\mathrm{Mal}_{1}$-globulin } & N.T. & & 49 \\
\hline & $60^{\circ} \mathrm{C}$ & + & 73 \\
\hline & $70^{\circ} \mathrm{C}$ & ++ & 85 \\
\hline \multirow[t]{3}{*}{$\mathrm{Mal}_{2}$-globulin } & N.T. & & 19 \\
\hline & $60^{\circ} \mathrm{C}$ & + & 33 \\
\hline & $70^{\circ} \mathrm{C}$ & ++ & 62 \\
\hline \multirow[t]{3}{*}{ Cit-globulin } & N.T. & & 44 \\
\hline & $60^{\circ} \mathrm{C}$ & + & 101 \\
\hline & $70^{\circ} \mathrm{C}$ & ++ & 100 \\
\hline \multirow[t]{3}{*}{$\mathrm{dMal}_{1}$-globulin } & N.T. & & 102 \\
\hline & $60^{\circ} \mathrm{C}$ & - & 101 \\
\hline & $70^{\circ} \mathrm{C}$ & - & 102 \\
\hline \multirow[t]{3}{*}{ dCit-globulin } & N.T. & & 101 \\
\hline & $60^{\circ} \mathrm{C}$ & - & 96 \\
\hline & $70^{\circ} \mathrm{C}$ & - & 92 \\
\hline
\end{tabular}

a The minus, one plus, and two plusses represent no gel formation, soft gel formation and hard gel formation, respectively.

b The number of trinitrobenzene sulfonate-reactive amino groups in native globulin without thermal treatment is expressed as $100 \%$.

c N.T. represents no thermal treatment. 
and $56 \%$ of the amino groups were acylated in $\mathrm{Mal}_{1}-$, $\mathrm{Mal}_{2-}$ and Cit-globulin, respectively. After the gelation treatment, the number of free amino groups were partially reversed in $\mathrm{Mal}_{1}$ - and $\mathrm{Mal}_{2}$-globulins, and completely in Cit-globulin. These observations are consistent with the previous data showing that amino groups acylated with maleic or citraconic anhydride can be reversed by incubating in acidic conditions. ${ }^{7}$

It was tested whether the gelation of acylated globulins depends on some secondary effects including protein denaturation. The $\mathrm{Mal}_{1}$ - and Cit-globulins were deacylated by dialyzing modified protein solutions against $10 \mathrm{mM}$ acetate buffer at $\mathrm{pH} 2.0$ for $42 \mathrm{hr}$ and $4 \mathrm{hr}$, respectively (the deacylated proteins are respectively termed $\mathrm{dMal}_{1}$ - and dCit-globulin). The deacylated proteins were tested for their ability to form thermally induced gels in the same way. The solutions containing the deacylated globulins were more viscous than native globulin solution both before and after thermal treatment, suggesting that some denaturation may have been accompanied by acylation and subsequent deacylation. However, as shown in Table $\mathrm{I}$, no gel formation was seen when the $\mathrm{dMal}_{1}$ - and dCitglobulins were incubated at $60^{\circ} \mathrm{C}$ or $70^{\circ} \mathrm{C}$. The lack of gelation in the deacylated globulins indicates that during the gelation process under acidic conditions, some of the amino groups may need to be acylated. In the case of dCitglobulin, deacylation may have been completed after the important processes for gelation were finished.

In conclusion, the thermal gelation of $13 \mathrm{~S}$ globulin could be induced under acidic conditions by its acylation with maleic and citraconic anhydrides. In Cit-globulin at least, the modified protein was completely deacylated during gelation treatments. If the released citraconic acid has been removed by dialysis, sesame $13 \mathrm{~S}$ globulin gels can be made safely edible.

\section{REFERENCES}

1) K. Hasegawa, K. Maeda, Y. Fujino, T. Wakinaga and S. Fujino, Nippon Nôgeikagaku Kaishi, 52, 341 (1978).

2) K. Hasegawa, K. Owaki, A. Tomita and S. Fujino, Nippon Nôgeikagaku Kaishi, 53, 375 (1979).

3) S. Fujino, Y. Kamiguchi, Y. Yokoi and K. Hasegawa, Nippon Nôgeikagaku Kaishi, 55, 975 (1981).

4) M. Sternberg and C. Y. Kim, "Protein Crosslinking, Nutritional and Medical Consequences," ed. by M. Friedman, Plenum Press, New York, 1977, p. 73.

5) R. J. G. Butler and B. S. Hartley, "Methods in Enzymology," Vol. XXV B, ed. by C. H. W. Hirs and S. N. Timasheff, Academic Press, New York, 1972, p. 191.

6) R. Haynes, D. T. Osuga and R. E. Feeney; Biochemistry, 6, 541 (1967).

7) J. K. Shetty and J. E. Kinsella, "Modification of Proteins," ed. by R. E. Feeney and J. R. Whitaker, American Chemical Society, Washington D. C., 1982, p. 169. 